\title{
School Effectiveness and Inclusion: Cases of Selected Secondary Schools in the Free State, South Africa
}

\author{
T. M. Makoelle \\ University of Johannesburg, South Africa, Department of Educational Psychology, \\ P.O. Box 524, Auckland Park, Johannesburg 2006 South Africa \\ E-mail: tmakoelle@uj.ac.za
}

KEYWORDS Effective School. Effective Leadership. Inclusive Education. Integration. Learner Attainment

\begin{abstract}
The promulgation of the White Paper 6 in 2001 has laid the basis for the implementation of inclusive education in South Africa. However, South Africa has both effective schools which are known of quality teaching and learning and also less effective schools with poor teaching and learning. School effectiveness is mostly thought to be at the heart of effective implementation of educational practices including inclusive education. Therefore this paper examines the relationship between school effectiveness and the extent to which it impacts the practice of inclusion in secondary schools. The study was generatively qualitative and assumed a case study research design wherein data was collected by means of face to face interviews with secondary school principals and focus group interviews with school governing bodies and school management team members. Data was then analysed using constant comparative analysis within an inductive analytical framework. Among the finding of the study was that effective schools had effective leadership, well informed School Based Support Team and high collaboration among management leadership which were instrumental in enhancing inclusive practices within an effective school.
\end{abstract}

\section{INTRODUCTION}

The concept school effectiveness in South Africa is mostly linked to learner achievement (NEEDU 2009; Makoelle 2012b), and the debates around school effectiveness revolve around the matriculation results of secondary schools. Schools with poor matriculation results are generally assumed to be less effective, as suggested by the following definition of Scheerens (2004:4), which is consistent with the South African understanding of school effectiveness: 'school-effectiveness research is the association of hypothetical effectiveness enhancing conditions of schooling and output measures, mostly student achievement.'

Scheerens (2004) uses the systems analogy to conceptualise school effectiveness (that is, the input effect on throughput and the resultant output of the education system). Meaning the process by which the school is the system that accommodates learners (input), teach them (throughput) and expect results (output) (Scheerens 2013). The notion of quality is regarded as integral to school effectiveness, as educational output is a basic criterion for measuring quality.

However, in South Africa, the achievement of good results has been the yardstick for evaluating school effectiveness; however, according to Taylor (in Townsend 2007), the notion of achievement-oriented conceptualisations of school effectiveness led to the Department of Education initiating the School-Based Accountability (SBA) measures, which focus on testing, not on capacity-building. The SBA is used to manipulate results by eliminating high-risk candidates, encouraging registration at standard grade, lowering the standard of question papers and raising scores during moderation. These processes resulted in the perceived high pass rates but actual poor quality.

The impression created was that schools are effective based on high pass rates, but the facts suggest differently. The achievement drive led to several initiatives to improve the performance of schools, but there is a re-emergence of the debates around quality assurance and ensuring quality education at schools. Since 1994 there is a general perception that the quality has deteriorated (Christie et al. 2007), which has led to various studies on quality in education.

Botha (2000:3), for example, in linking quality with school effectiveness in the new education dispensation, defines quality within Total Quality Management (TQM) (one of the strategies to improve education in post-apartheid South Africa) as:

... factors such as learner achievement, teaching approaches and the nature (physical, cultural and social) of the school. Quality 
in the classroom also raises issues such as the aims, goals and means of teachers and learners.

Enhancing the quality at schools requires effective teaching and learning, which will result in learners achieving the expected outcomes. While Botha (2000) understands quality to mean the above, he emphasises that, for quality to be achieved, theory must be linked to practice and that sustainable improvement towards quality education can only take place if organisations identify and solve practical problems to enhance the quality of their organisations. This argument is shared by Motata (2000), who postulates that there is a large gap between South African policies and the reality at schools in that new policies have not necessarily translated into quality teaching and learning at schools. Motata (2000) suggests that more qualitative and empirical school and classroom research is needed.

On the other hand, the implementation of inclusive education in South Africa came in the midst of curricular changes instituted by the government led by the African National Congress (ANC) since 1994 (Naiker 2005). The broad transformation of South African society towards equality coincided with the initiation of inclusion as promulgated in international documents such as the Salamanca Statement (1994) and Dakar World Education Forum (2000) (Engelbrecht 2006; Nkoane 2006).

Before 1994, the schooling system was based on a racial and special-needs education approach (Engelbrecht 1999; Engelbrecht et al. 2002). After 1994, the segregated system began to be replaced by a unified schooling system (Christie 1995; Nkomo 1990). However, there is a need to acknowledge that, although formal desegregation began after 1994, de facto desegregation had begun in the late 1970 s to mid-1980s. According to King (2001), the notion of an integrated and comprehensive approach to inclusion focused on a critical review of institutional policies, practices and programmes, which implies adopting a holistic approach to inclusion (Makoelle 2013). The implementation of inclusive education in South Africa became part of the broad social transformation of society (Engelbrecht and Waghid 2002; Sayed and Carrim 1998; Soudien and Sayed 2004). Mitchell (2005) describes this period as a paradigm shift from special and ordinary categories of schooling to a single system (Makoelle 2013). But Hay et al. (2006) found that teachers' frames of thought were informed by the past regime, which made them less ready to implement inclusion (Makoelle 2014). The government of South Africa drafted policies that sought to ensure the implementation of inclusive education, conceptualised in Vision 2021 as indicated in White Paper 6 (DoE 2002:43). Various guideline documents were published to facilitate the implementation of inclusive education. However, since the start of the transformation process, a great deal has been said in documents and papers, but whether these documents have translated into action, especially in developing inclusion in classrooms and ensuring that teachers are fully equipped to handle an inclusive class, remains an open question (Makoelle 2012a).

Parallel to the process of implementing inclusion, the South African government implemented Curriculum 2005 which underpinned outcomes-based education (OBE) designed to bring about an inclusive culture of teaching and learning. The implementation of the outcomesbased education system through the announcement of the National Curriculum Statements (NCS) for the General Education and Training band (GET: Grades 8-9) and Further Education and Training band (FET: Grades 10-12) became the initial step in the provision of equal opportunities for all (Makoelle 2004). The plan to introduce inclusive education was further highlighted in White Paper 6 (2001), culminating in Vision 2021 which will see inclusive education implemented at all levels of schooling. The FET sector (secondary schools included) envisaged implementing inclusion from the year 2008. Since then inclusive education has been implemented at the primary and secondary level of schooling, and the notion of full service schools is being phased in gradually. The accommodation of learners with diverse abilities and needs into mainstream school have presented some challenges of school effectiveness as this calls for new innovative ways of management and leadership in schools.

\section{Aim of the Study}

However, while there have been studies on school effectiveness and inclusion in South African schools little is known about how the implementation of inclusive education have affected the effectiveness of schools given the accommodation of learners with diverse abilities 
and needs. Therefore what prompted the study was to answer these research questions:

Is there a relationship between school effectiveness and inclusion?

Which effective management practices enhance the implementation of inclusion?

\section{Conceptualising School Effectiveness and Inclusion}

When an organisation accomplishes its specific objective, it is said to be effective (Beare et al. 1989:11; Makoelle 2012b). As this clearly holds true for schools as well, it is necessary to distinguish between school effectiveness and school efficiency. School efficiency refers to accomplishing an end without a waste of effort or resources (Beare et al. 1989: 11). School efficiency is a distinct characteristic of an effective school (Makoelle 2012b).

By contrast, the much broader concept school effectiveness could mean different things to different people in different contexts - indeed, there has been global and international debate around the meaning of the concept (Mortimore 2000). The concept is mostly associated with learner attainment, but it could also be associated with how well the school functions. Davies (in Ainscow 1999: 97), had the following to say about school effectiveness:

... the myth [is] that everyone from the government downwards would like school effectiveness, but there are just too many materials or attitudinal constraints on the implementation. In fact, government do not want effective schools in the academic or vocational sense. The last thing a fragile state wants is too many articulate, well qualified students.

The notion of school effectiveness is usually associated with the notion of an effective school. Bennet et al. (2003: 176) define an effective school as one '... in which students progress further than might be expected from consideration of its intake'. This definition has similar elements to those advanced by Mortimore (in Sammons 1999), who stresses that the school has the responsibility to ensure that the success of all its learners will be measured by how well the school attains its objectives, and how well its learners achieve the expected outcomes. According to Sammons (1999: 76), the process of school effectiveness is affected by numerous factors, such as the sample of schools, choice of outcome measures, and the methodology and time scale.

These factors also indicate why some schools succeed while others fail. Some schools are more effective than others; even learners from different schools achieve different outcomes. Morley and Rassool (1999: 68) highlight the fact that school effectiveness as a paradigm is based on two distinct discourses; that is, management and organisation. The organisation of the school often has a predestined structure prescribed by the education authorities. In other words, the effectiveness of the school could be imposed by the government by virtue of the design of evaluation tools such as checklists and inspections, which may not necessarily enhance effectiveness but seek to determine learner attainment. Conversely, Harris et al. (1997: 1) highlight the political nature of school effectiveness by noting that governments determine how schools should function because of the valuefor-money idea as a considerable amount of investment could have gone into the education budget.

However, the dominance of the government's view is challenged by the view that, in the management of the school, three dominant aspects are at play, namely leadership, marketing and the role of the parents and school community. School effectiveness could indicate how well the school is managed by the principal, how well parents and the community are involved in its activities, and how well the school is known (Hajnal et al. 1998).

In most countries, the management politics of school effectiveness is often associated with effective leadership. Bennet et al. (2003:176) contest this notion but nevertheless choose to list the main characteristics of an effective principal as the leader of the school, pointing out that he/ she should: be an experienced teacher; understand children; be firm; be able to manage the environment; be accountable for the functioning of the school; inspire the school community; be an example; be inclusive in his/her approach and treat everyone equally.

These varied contextualizations of school effectiveness seem to expose a multiplicity of understandings, which suggests that the prevailing definition of school effectiveness may not be conclusive as context plays an important role. However, for the purposes of this study, school effectiveness will be assumed to mean 
the state at which the school functions properly in all respects and experiences high learner attainment.

On the other hand the notion of inclusion from a global perspective seems to be conceptualised differently as countries have varying contexts, which influences how it is practised and implemented (Dyson 2001; Artiles and Dyson 2005; Fletcher and Florian 2009). The concept is so widely regarded to be a context-bound word that there is confusion about its use and meaning (Clough and Corbett 2000; O’Brien 2001). Ainscow (2009) refers to inclusion as a process of reorganising the school to be responsive to the needs of all its learners, while other researchers conceptualise inclusion as a goal to bring about an inclusive society (Artiles and Kozleski 2007).

The different interpretations have made it impossible to formulate a universal, context-free definition of inclusion. The multiple definitions of inclusion have resulted in the different practices of inclusion at pedagogical level, thus prompting questions about the nature of inclusive pedagogic practice.

It follows that there are many theoretical orientations in relation to what constitutes an inclusive pedagogic practice. Five main theoretical positions have been found quite dominant in the literature. The different perspectives on inclusion have been influenced by the way any given society construes the meaning of inclusion. This was over the years looked at from the following angles, approaches or models, according to Clough and Corbett (2000);

- Curriculum approaches model which is the model that involves viewing the curriculum as having the potential to act as a barrier to learning by itself, if the curriculum is not inclusive and not targeted towards a diverse learner population.

- School improvement strategies model which departs from the premise that the way the school is organised could act as a barrier to learning as well. For example, there is growing tendency to focus on pass rates ostensibly in the interests of raising standards and to exclude those whose performance is perceived to be weak (Ainscow et al. 2012).

- Disability model which suggests that the physical or psychological attributes of the learner render him/her a victim of exclusion; for example, learners with perceived physical and/or psychological defects (the deaf) are deliberately excluded.

- Pedagogic approach stemming from the medical deficit model, in terms of which teaching and learning are designed to address the perceived learners' medically diagnosed shortcomings. According to this model, the learner is perceived to have a handicap hampering effective learning.

- Social ecological model, which developed as a critique to the medical deficit model, where the learner's social context forms the core of accepting diversity and allowing participation of individuals regardless of the differences (Reindal 2008; Cesar and Ainscow 2006; Landsberg et al. 2011).

The indication in the literature is that there has been a steady shift from the medical to the socio-ecological model. However, despite these developments and paradigm shifts, there remains the highly contested issue of how full participation and inclusion could be achieved, further resulting in debates about the existence of an inclusive pedagogy. For instance, Thomas and Loxley (2001: 41) provide a critique of inclusion by advancing the argument by those against inclusion: There is an inconsistency between the principle of inclusion and evidence that it works (Makoelle 2012a).

These sentiments have lately been echoed by Hornby (2012) and Farrell (2010) articulating negative comments about inclusion raising doubts and questions about the merits of inclusion as opposed to those of special need education.

While the above arguments cast doubt on the relevance and applicability of inclusion, its development has been tracked and characterised by several studies. There have been several theoretical stances as a result of the two philosophical positions, For instance, full inclusion has been contrasted with the notion of integration:

All forms of integration assume some type of assimilation of the disabled learners into the mainstream school largely unchanged. Inclusion is not a static state like integration. It is a continuing process of school ethos and change. It is about building [a] school community that accepts and value differences (Florian 2007: 37).

The above quotation argues that simply putting learners in the mainstream school without adequate measures to respond to their needs is contrary to the aspirations of full inclusion. On 
the other hand, according to Ainscow and Farrell (2002) a distinction between integration and inclusion could be derived from the placement of learners according to three broad approaches:

- Location, which means classes are located within the mainstream campus;

- Social, where interaction of learners during social activities at schools, for example, at mealtimes and;

- Functional which is putting learners with difficulties in the mainstream classes along their peers).

Inclusion according to the latter approach involves welcoming the learners as full members of the class regardless of the differences.

It follows that the various theoretical and philosophical stances of inclusion have farreaching implications as a result of how those who adopt them will define inclusive education. For example, there is a perspective by Farrell (1997), Rief and Heimburge (2006) and others that inclusive education involves applying special-education strategies within the mainstream schools; however, there is a counter-argument that inclusion is an alternative approach to special education, goes beyond such strategies, and draws on the creativity and novelty of teachers (Ainscow 2010; Ballard 1999). While there are different views about what inclusion is and therefore doubts about its merits, it remains a critical aspect that for school effectiveness and functioning as schools are expected to implement inclusive education. This paper therefore analyses the relationship between the processes of implementing inclusive education, as it bring new challenges to the complexity of school management and thus on school effectiveness.

\section{METHODOLOGY}

Qualitative research is intended principally to interrogate both the research process and the end-product of the research. It differs from the quantitative approach in that the process is not aimed at the generalisation of findings but focuses on achieving a deeper understanding of the phenomenon being studied. The data collected qualitatively are tacit (intuitive) and their reliability and validity depend on what Lincoln and Guba (1985) call 'trustworthiness' (Cresswell 2003: 186). While some researchers often regard qualitative and quantitative research ap- proaches as competing paradigms, researchers such as Cresswell (2003) view them as mutually complementary to the research process. This study, however, used a qualitative research approach because it allowed the study to be conducted in natural settings, where the perceptions and experiences of the researcher and the researched could be taken into consideration for the purposes of understanding and describing the data (Motaboli 2009). In linking the casestudy method with qualitative research, Noor (2008) describes the case-study method as a strategic qualitative method. The relationship between the qualitative research approach and case study mostly stems from the need to generate a deeper understanding of the phenomenon and to take the perceptions and experiences of research subjects into consideration. The goal of the case-study method is therefore to generate meanings to understand the phenomenon being studied (Noor 2008).

The case-study method is in many instances used together with the qualitative research approach, because the phenomenon is studied in a real-life context. Case studies are mostly concerned with why and how things happen, clarifying the difference between the contexts of what was planned and what actually happened during an inquiry. This leads to an in-depth understanding of the phenomenon (Yin 2003; Noor 2008).

\section{Population and Sampling}

Population is defined by Neuman (2006: 224) as the abstract idea of a large group of cases from which a researcher draws a sample from which results are generalised. Sapsford (2007) adds that population means the entire set of objects spoken about and about which generalisations are made. The population in this study therefore comprises all secondary schools in the Free State Province.

Sample is defined by Neuman (2006: 218) as a small set of cases a researcher selects from a larger pool and generalises to the population. For logistical reasons, such as resources and time, only six secondary schools in a selected district of the Free State Province were selected to constitute a sample. The schools in the district were selected purposefully, which means that a sample was constituted according to the availability of subjects rather than on the basis of representativeness (Leedy 1993). 
The sample comprised of three highly effective schools and three less effective schools in terms of learner achievement. Documentary analyses of the six schools were done. The sampling of schools was done in a random manner, using a quota-sampling technique. Neuman (2006: 220) describes quota sampling as:

Getting a preset number of each of several predetermined categories that will reflect the diversity of the population using haphazard method.

Stringer (2008) and Sapsford (2007) support this definition of quota sampling. Three highly effective schools and three less effective schools were selected on the basis of their matriculation results. Schools with a more than $80 \%$ pass rate were regarded as highly effective and schools with a less than $60 \%$ pass rate as less effective schools. The $60 \%$ and $80 \%$ bench-marks were used as a distinguishing factor to highly effective and less effective schools given the Free State provincial average in pass-rates. While these thresholds were used for determining the level of effectiveness in the Free State Province, caution should be exercised as $60 \%$ could be regarded as highly effective in other provinces or in other contexts. The results used were culled from the years 2007, 2008 and 2009.

The participants in the study and how data was collected from the six schools are summarised in Table 1.

\section{Data Collection}

The semi-structured interview is a personto-person conversation with the objective of exploring the research topic with the research participant (Watts and Ebbutt 1987; Trochim 2001; Bryman 2001; Burton 2000; Yates 2004; Cresswell 2003; Wengraf 2001). One-on-one interviews with principals and school-based focus-group interviews were the first phase in the qualitative phase. During this phase, six (6) semistructured interviews were conducted with each of the six principals of the selected schools $(1 \times 6=6)$ (see Table 1).

Table 1: Summary of participants

\begin{tabular}{llc}
\hline Participants & Place & Number \\
\hline Principals & Schools & 6 \\
SGB focus group & Schools & 6 \\
School-management team & Schools & 6 \\
focus group & & \\
\hline
\end{tabular}

According to Babbie (2004: 302), a focus group is 'a group of 6 to12 people brought together in a room to engage in a guided discussion about some topic.' The same definition is supported by Wong (2008), Krueger (1994), Laws et al. (2003), Kelly (1998) and Wilson (1997). Focus-group interviews with three different focus groups, also purposefully sampled, consisted of six School Management Teams (SMT) members, six School Governing Body (SGB) members and six teachers from each school followed (see Table 1).

\section{Data Analysis}

The analysis of qualitative data, according to Blaikie (2000), therefore takes into consideration the views of participants and the process and context. According to Mouton (2001: 108), the aim of data analysis is to understand the components of data and determine the relationship between variables, patterns and themes. Data analysis results in interpretation, which involves synthesising data into a coherent whole.

The researcher attempted to make sense of all the data collected qualitatively; that is, from unstructured interviews, SGB focus-group interviews, and documentary analysis. The researcher used a systematic set of procedures to develop and inductively derive theory about the phenomenon, a principle borrowed from grounded theory (Strauss and Corbin 1990: 24). The developmental data analysis was characterised by the following series of basic steps (Laws et al. 2003: 395):

- Step 1: Reading and rereading all the collected data.

Reading the data ensured that the researcher was familiar with the data, thus making the process of analysis much easier and more manageable.

- Step 2: Making a preliminary list of themes arising from the data

The process of categorising data into themes, referred to as 'coding', has been conceptualised by Miles and Huberman (1994) as labels or texts assigned to units of meaning of pieces of data collected. Similarly, Neuman (1997) refers to the process as organising raw data into conceptual categories in order to create themes that will be used to analyse the data. Consequently, the data were categorised into themes. 
- Step 3: Reading the data again to confirm the themes

It is crucial that data be studied several times to verify that the interpretations are correct and valid. The data were read several times to confirm the themes.

- Step 4: Linking themes to quotations and notes

The researcher then wrote themes next to the quotations and notes while examining the data.

- Step 5: Examining and interpreting the categories of themes

From the meaning attached to the interpretations of themes, logical conclusions were drawn.

\section{RESULTS}

When analysing the responses of principals, SMT members and SGB members of participating schools the following themes emerged:

\section{Theme 1: Inclusion as Part of the Vision and Mission of the School}

Highly effective School A, appeared to have made inclusion part of their mission for example the principal emphasised: "inclusion is crucial for our school community because we have made it part of our vision and what we ought to integrate into the mission of the school"

However, it seemed as though less effective school $\mathrm{F}$ while claiming to be taking inclusion seriously they have not made inclusion part of the vision and mission, so it seemed as though that inclusion was not well articulated for instance one SMT member said "while we have not outlined inclusion in our vision and mission we regard it as important",

\section{Theme 2: Inclusion as Part of School Development Plan (SDP)}

Data revealed that in the highly effective School C inclusion was made one of the core strategic thrusts of the SDP, for instance one member of the SGB indicated: "when we drew the SIP inclusion was identified as our area of focus for the next three years, because we realised it is an area where we needed to improve". While the less effective schools showed less prioritisation of inclusion in their planning. To support this the following quote from the SMT member of less effective School E provides evidence "to be honest we have not captured inclusive education in our SIP in fact we believe its policy so its obvious we have to implement"

\section{Theme 3: Effective Control on Inclusive Curriculum Delivery}

There was an indication that in highly effective school B the SMT ensured through control of work that teaching responded to the needs of learners for instance the principal of an effective school alluded " we hold subject meeting with teachers to reflect about how we should approach each subject inclusively such that all learners have access". On the contrary in less effective school D there appeared to be less control on the general curriculum delivery process which was an indication that even inclusion is not monitored, one of the SMT members had this to say: "we have difficulty in assessing and checking what teachers are doing because of unions, even the implementation of inclusion, we can't comment"

\section{Theme 4: Learner Performance Review in Inclusive Classroom Contexts}

Analysis indicated that in highly effective schools, for example in School A learners' performances are reviewed frequently to determine the effect of inclusion. For instance the principal of School A mentioned "we review the work of learners particularly to look at the effect of our classroom teaching as part of our intervention to ensure that teaching accommodate the needs of all learners including those with special educational needs." However it was revealed that in less effective schools the review of learner performances in relation to how teaching has accommodated diverse learner population does not occur regularly, for example the SMT member of a less effective School F alluded "we do review performance of all learners but we do that at the end of the year, but still we focus of the overall performance rather that of certain groups"

\section{Theme 5: Effective Management of School Based Support Team for Inclusion}

Data indicated that highly effective schools have proper monitoring procedures of SBSTs 
and their operations, the SBST is incorporated into abroad management where issues of learner support and inclusion are discussed for example in School B the principal said "we review the performance of the SBST regularly and we sit in the management meeting with the SBST at least once a month to get a perspective of challenges and successes of the team and look at way by which we can intervene of provide support" while at less effective schools management do discuss the issues of inclusion is looked as though that the SBST was not directly involved at management level to review its operations and to reflect on challenges and success, for example the SMT member of School E posited "yes, we are controlling the work of the SBST but we do not involve them at management level, most of them are PL1 educators."

\section{Theme 6: Involvement of Stakeholders for Inclusion}

Data point out that there was high stakeholder involvement with regard to matters of inclusion and support. There was a clear integrated plan to involve local organisations with vested interest to inclusion as a form of social justice, for instance the principal of highly effective school B alluded "we meet the stakeholders with keen interest in inclusion at the beginning of every year to discuss how they can provide support to the school in enhancing an inclusive school environment, then we draw a joint strategy" the indication in less effective schools was that although they involve parents of learners bay way of parents meeting on issues of inclusion, they have not gone far in involving other stakeholders other than parents, for example the principal of School D said "We do involve parents but only to report on our results we seldom involve other stakeholders."

\section{DISCUSSION}

The findings of the study are discussed according how far the research questions were answered. The research questions are therefore restated and discussed.

\section{Is There a Relationship between School Effectiveness and Inclusion?}

The analysis indicated that there is a strong relationship between school effectiveness and inclusion. Highly effective schools seem to have incorporated inclusion within their vision and mission and school development planning. The curriculum delivery processes are planned and monitored to effectively enhance inclusion. The process of teaching is reviewed regularly against the purpose of improving the inclusive conditions in the classroom. The SBSTs are involved directly at management level and are made part of the planning, decision-making and implementation process. There is clear involvement of stakeholders and collaboration to enhance inclusive practices.

\section{Which Effective Management Practices Enhance the Implementation of Inclusion?}

The study has found that encompassing inclusion within the school's vision and mission gives purpose and direction to implementation of inclusion. That the implementation of inclusion be infused into the Strategic school development planning such that it becomes part of school improvement plan. It is also evident that frequent reviews of learner performances seem a good management practice as it indicates how and when interventions are necessary for improving inclusive educational environments. To assess the impact of inclusion in the classroom it seems as though it is a good management practice to constantly reflect and review learner performance which will inform the need for improvement. Consultative engagement between leadership and SBSTs seem to be indispensable as it gives the school management and SBST holistic perspective of the state of inclusion in the school, challenges and how it could be improved. Involvement of stakeholders in highly effective schools seem to be an important aspect of enhancing inclusion as stakeholders give support and bring with different ideas which could be helpful to an inclusive school.

\section{CONCLUSION}

While there are few studies which link inclusion to school effectiveness, this study constituted laid the foundation for further exploration of the link between the two concepts. The study makes a valuable contribution to the implementation of inclusive education in South Africa or countries with similar contexts.

\section{RECOMMENDATIONS}

It is therefore, given the findings of the study recommended that schools incorporate inclusion as part of their vision and missions, that the 
process of school development planning puts inclusion as one of the main strategic goals. School management teams must on a frequent basis assess how inclusive the delivery of curriculums is, such that appropriate interventions could be planned and executed. The school management should also review the performances of learners within inclusive contexts such that the state of inclusive teaching and learning could be determined. It is also appropriate to recommend that school management teams directly involve the SBST in management issues that relate to inclusion directly which will minimise problems during implementation. Lastly schools must involve other stakeholders in determining alternative practices which could improve the state of inclusion in schools.

\section{REFERENCES}

Ainscow M 1999. Understanding the Development of Inclusive Schools. London: Routledge Falmer.

Ainscow M 2010. Developing Inclusive Education Systems: The Role of Organisational Cultures and Leadership. London: Taylor and Francis.

Ainscow M, Dyson A, Goldrick S, West M 2012. Making schools effective for all: rethinking the task. School Leadership and Management, 32(3): 197213.

Artiles AJ, Dyson A 2005. Inclusive education in the globalization age. Contextualizing Inclusive Education, 37-62.

Artiles AJ, Kozleski EB 2007. Beyond convictions: Interrogating culture, history, and power in inclusive education. Language Arts, 84(4): 357.

Ballard K 1999. Inclusive education: International voices on disability and justice. Routledge.

Beare H, Caldwell BJ, Millikan RH 1989. Creating an Excelling School. New York: Routledge.

Bennet N, Crawford M, Cartwright M 2003. Effective Educational Leadership. London: Paul Chapman Publishing.

Botha RJ 2000. Outcomes-based education and quality: Cursory remarks about a possible relationship. Educare, 29(1 and 2): 129-141.

Christie P 1995.Transition tricks? Policy models for school desegregation in South Africa, 1990-94. Journal of Education Policy, 10(1): 45-55.

Christie P, Butler D, Potterton M 2007. Ministerial Committee Report on Schools that Work. Pretoria: DoE.

Clough P, Corbett J 2000. Theories of Inclusive Education: A Student Guide. London: Paul Chapman Publishing.

Department of Education 2002. Draft Guidelines for the Implementation of Inclusive Education. Department of Education. Pretoria: Government Printers.

Department of Education 2009. National Education and Evaluation Development Report. Government Gazette, 526 (32133). Pretoria: Government Printers.
Dyson A 2001. Special needs education as the way to equity: An alternative approach? Support for Learning, 16(3): 99-104.

Engelbrecht P 1999. A theoretical framework for inclusive education. In: P Engelbrecht, L Green, S Naicker, L Engelbrecht (Eds.): Inclusive Education in Action in South Africa. Pretoria: J.L. Van Schaik, pp. 3-12.

Engelbrecht P 2006. The implementation of inclusive education in South Africa after ten years of democracy. European Journal of Education, XXI (3): 253264.

Engelbrecht P, Howell C, Bassat D 2002. Educational reform and the delivery of transition services in South Africa: Vision, reform and change. Career Development of Exceptional Individuals, 25(2): 5972.

Farrell P 1997. Teaching Pupils with Learning Difficulties. London: Cassel.

Farrell P, Ainscow M 2002. Making Special Education Inclusive. London: David Fulton Publishers.

Florian L 2007. The Sage Handbook of Special Education. London: Sage Publication.

Florian L 2009. Towards inclusive pedagogy. Psychology for Inclusive Education: New Directions in Theory and Practice, 38-51.

Hajna V, Walker K, Sackney L 1998. Leadership, organisational learning and selected factors relating to the institutionalization of school improvement initiatives. Journal of Education Research, 44(1): $70-89$.

Harris A, Bennet N, Preedy M 1997.Organizational Effectiveness and Improvement in Education. Buckingham: Open University Press.

Hay J F, Smit J, Paulsen M 2006.Teacher preparedness for inclusive education. South African Journal of Education, 21(4): 213-218.

Hornby G 2012. Inclusive education for children with special educational needs: a critique of policy and practice in New Zealand. Journal of International and Comparative Education, 1(1): 52-60

King KL 2001. From numerical to comprehensive inclusion utilizing experiences in the USA and South Africa to conceptualize a multicultural environment. International Journal of Inclusive Education, 5(1): 67-84.

Landsberg E, Kruger D, Swart E 2011. Addressing Barriers to Learning: A South African Perspective. $2^{\text {nd }}$ Edition. Pretoria: Van Schaik.

Makoelle TM 2004. Factors Contributing to Scholastic Achievement by Secondary School Learners in the Setsoto Municipality Area. MEd. Dissertation, Unpublished. University of the Free State, Bloemfontein.

Makoelle TM 2012a. The state of inclusive pedagogy in South Africa: A literature review. Journal of Sociology and Social Anthropology, 3(2): 93-102.

Makoelle TM 2012b. School Effectiveness and Improvement in South Africa. Germany: Lambert Academic Publishing.

Makoelle TM 2013. Inclusive Pedagogy in Context: A South African Perspective. Germany: Lambert Academic Publishing.

Makoelle TM 2014. Changing teacher beliefs and attitudes towards inclusion in South Africa: Lessons from 
collaborative action research. Journal of Social Sciences, 38(2): 125-134.

Mitchell D 2005. Contextualizing Inclusive Education. London: Routledge, Taylor and Francis Group.

Naicker S 2005. Inclusive education in South Africa: An emerging pedagogy of possibility in Mitchell D 2005. Contextualizing Inclusive Education: Evaluating Old and New International Perspectives. London: Routledge, Taylor \& Francis, pp. 230-252.

Nkoane MM 2006. An Analysis of Factors Inhibiting the Access of Students with Special Educational Needs to Higher Education in the Free State. PhD Thesis. Bloemfontein: University of Free State.

Nkomo MO (Ed.) 1990. Pedagogy of Domination: Toward a Democratic Education in South Africa. New Jersey: Africa World Press

O’Brien T 2001. Enabling Inclusion Blue Skies... Dark Clouds. London: The Stationary Office.

Rassool N, Morley L 1999. School Effectiveness Fracturing the Discourse. London: Falmer Press, Taylor and Francis Group.

Reindal SM 2008. A social relational model of disability: A theoretical framework for special needs education? European Journal of Special Needs Education, 23(2): 135-146.

Rief S, Heimburge JA 2006. How to Reach and Teach All Children in the Inclusive 250 Classroom: Practical Strategies, Lessons and Activities. $2^{\text {nd }}$ Edition. London: Jossey-Bass Publishers.

Mortimore P 2000. Globalization, Effectiveness and Improvement. Paper presented at the Annual Meeting of the $13^{\text {th }}$ International Congress for School
Effectiveness and Improvement. Hong Kong, 4-8 January.

Motata S 2000. Quality and Indicators of Quality in South Africa: A Critical Appraisal. University of Witwatersrand: Education Policy Unit.

Sammons P 1999. School Effectiveness: Coming of Age in the Twenty-first Century. London: Swetz and Zeitlinger Publishers.

Sayed Y, Carrim N 1998. Inclusiveness and participation in discourse of educational governance in South Africa. International Journal of Inclusive Education, 2(1): 29- 43.

Scheerens J 2004. The Meaning of School Effectiveness. Presentation at the 2004 Summer School, December 6, Oporto, Portugal: ASA Publishers.

Scheerens, J 2013. The use of theory in school effectiveness research revisited. School Effectiveness and School Improvement, 24(1): 1-38.

Soudien C, Sayed Y 2004. A new racial state? Exclusion and inclusion in education policy and practice in South Africa. Perspectives in Education, 22(4): 101116.

Thomas G, Loxley A 2001. Deconstructing Special Education and Constructing Inclusion. $2^{\text {nd }}$ Edition. Maidenhead: Open University Press

Townsend T 2007. International Handbook of School Effectiveness and Improvement. Dordrecht: Springer. Waghid Y, Engelbrecht P 2002. Inclusive education, policy ad hope: Mapping democratic policy changes on inclusion in South Africa. International Journal of Special Education, 17(1): 20-25. 